Yves Lamarche MD FRCPC, Michel Lebel MD FRCPC, Réne Martin MD FRCPC

\section{EMLA partially relieves the pain of EMG needling}

Dans ce travail, nous avons voulu évaluer l'efficacité de la crême topique analgésique EMLA pour le soulagement des douleurs causées par l'introduction d'aiguilles cutanées et intramusculaires en électromyographie (EMG). Pendant les cliniques régulières d'EMG, 34 patients de 21 à 69 ans (moyenne $38,5 \pm$ 11,4), des deux sexes, de race blanche programmés pour une évaluation électromyographique, ont été étudiés. Une couche épaisse d'EMLA ou de placébo a été appliquée, à l'aveugle, a deux endroits sur chacun des membres supérieurs : au site E sur la face latéro-postérieure de l'avant-bras en aval du condyle externe, et au site A, sur l'éminence thénar. La randomisation avait préalablement établi que chaque fois qu'on appliquait de l'EMLA sur un des sites de l'avant-bras, le placébo était appliqué sur le site homologue de l'autre membre supérieur. Après au moins 45 minutes (de 45 à 145 minutes, en moyenne $72,3 \pm 22,2$ minutes) d'application de la substance, l'aiguille exploratrice a été introduite dans la peau et dans le muscle. A chacun des deux niveaux d'introduction, l'électromyographiste a demandé au patient d'évaluer la douleur ressentie sur une échelle visuelle analogique (EVA) de 1 à $10 \mathrm{~cm}$. Les résultats ont montré que sur le site $E$, la douleur était moins marquée lorsque la peau était recouverte par l'EMLA que lorsqu'elle l'avait été par le placébo (EVA $=0,75 \pm 1,36$ vs 3,10 $\pm 1,75, P=$ 0,0001 ). Le site non traité (placébo) E a été jugé moins douloureux que le site $A$ non traité (EVA $=3,10 \pm 1,75$ vs $6,09 \pm$ 1,96, $P=0,0001$ ). L'introduction dans le muscle extenseur commun des doigts au site $E$ s'est aussi effectuée avec moins de douleur lorsque la peau avait été traitée avec l'EMLA (EVA = $2,83 \pm 2,45$ vs 5,73 $\pm 2,30, P=0,0001$ ). Au site $A$, le degré de douleur a été le même quelque soit la nature de la substance appliquée. Nous n'avons pu établir de corrélation entre la durée d'application et l'EVA. Nous concluons que l'application d'EMLA est efficace pour analgésier la peau et le muscle extenseur commun des doigts à l'avant-bras mais inefficace sur la peau de l'éminence thénar et dans le muscle abducteur court du pouce pour la durée d'application adoptée.

Electromyography (EMG) is a well-established method for the investigation of muscle activity based on the recording of resting and action potentials for diagnosis purposes. It is helpful in the diagnosis of a wide variety of neuromuscular diseases. A needle connected to amplifiers and appropriate recording instruments has to be first intro- 
duced through the skin over the underlying muscles chosen for investigation. The introduction of a concentric needle of large calibre $(0.5 \mathrm{~mm})$ through the skin into a muscle is a painful procedure usually performed without analgesia. It is sometimes poorly tolerated by patients.

EMLA (Eutectic Mixture of Local Anaesthesia) is a 1:1 oil/water emulsion of an eutectic mixture (from the Greek $\epsilon U$, well, and $\tau \epsilon \kappa \tau \epsilon \iota \nu$, to melt) of lidocaine and prilocaine. It has penetrating properties that neither of its components can achieve alone at non-toxic concentrations. It has proved its topical analgesic properties in volunteers, ${ }^{1}$ in clinical situations on children and adults for intravenous ${ }^{1.2}$ and arterial cannulations. ${ }^{3}$ It is also under investigation for many other applications.

The aim of the present investigation was to study the efficiency of EMLA topical anaesthetic cream (Astra Pharma Inc.) in alleviating first the pain of skin needle insertion and second the pain of muscle insertion in a clinical situation (EMG).

\section{Methods}

Our study was approved by the ethics committees of both hospitals where the study was conducted. A signed informed consent was obtained from all patients. Thirtyfour (12 men, 22 women) patients aged 21 to $69 \mathrm{yr}$ (mean $38.56 \pm 11.43$ ) were included in the study which was originally designed to include 36 patients. A 77 -yr-old patient was excluded because she did not understand what was expected of her. In another case, results were deleted because of an error of identification of one of the coded tubes. Patients were chosen randomly from the normal schedule of EMG in the neurophysiology laboratory. Patients allergic to amide class local anaesthetics and presenting skin lesions were excluded from the study. At least $45 \mathrm{~min}$ (range 45-140 min, mean $72.3 \pm 22.2$ ) before the procedure, a technician applied $2 \mathrm{~g}$ of either EMLA or a placebo contained in coded tubes on two homologous sites of the upper limb marked earlier on each arm (Figure). The two sites were called $E$ site and $A$ site. The former (E site) is distal to the lateral epicondyle in the extensor muscle mass where the body of the muscle extensor digitorum projects. The latter (A site) is situated on the radial edge of the palm in the thenar eminence on the skin covering the muscle abductor pollicis brevis. The placebo could not be distinguished from EMLA by the patient, the technician or the electromyographist, its texture, colour and density being exactly the same as EMLA. The identical aluminium tubes containing EMLA or placebo were marked with coded numbers, by letters $A$ or E, left or right, obtained from a previously determined randomization table. Randomization of the tubes was such that when EMLA was applied blindly on one or both sites (A or E) of one arm, the placebo was applied on the

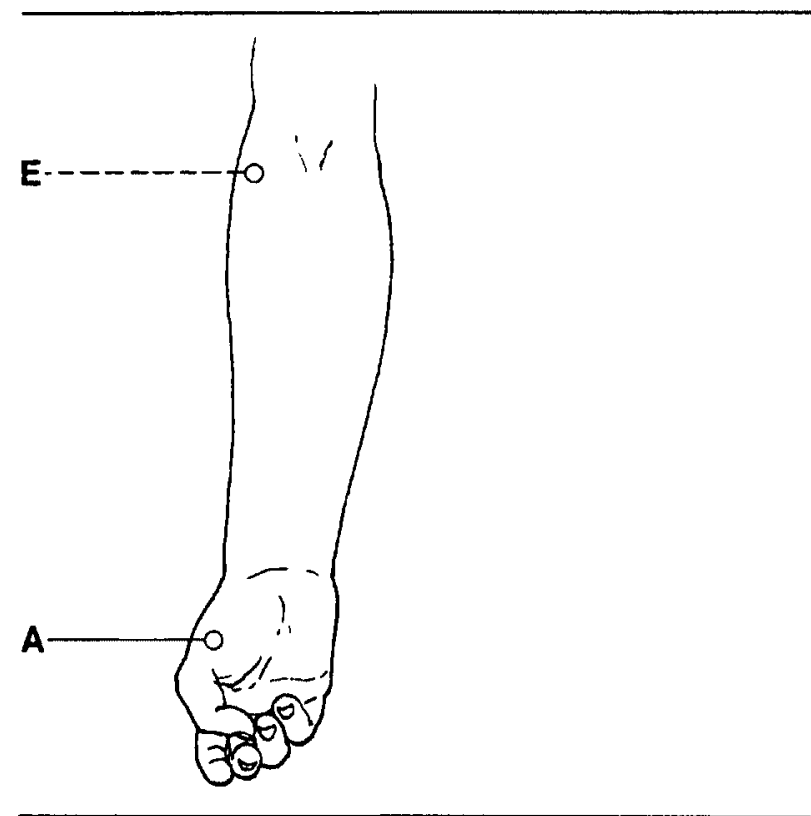

FIGURE Location of $\mathrm{T}$ and $\mathrm{E}$ site on the left arm. (---dorsal, - paimar).

homologous opposite side. The cream was covered by a transparent membrane (Tegaderm ${ }^{(\mathbb{D}}$ ) until the EMG session. Then the cream was removed and the skin disinfected with alcohol. At needle insertion on each of the four sites, the electromyographist asked the patient to score his degree of pain on a $10 \mathrm{~cm}(1=$ no pain, $10=$ worst pain $)$ visual analogue scale (VAS). The same procedure was repeated at muscle insertion. Muscle insertion was easily identified, the exploration electrode producing a characteristic burst of activity (insertion activity) rapidly subsiding. The results were recorded for future analysis. After completion of the study, a second investigator not immediately involved in the EMG procedure broke the code and compiled the results.

Comparisons were established between the effects of EMLA and placebo (VAS scores) with regards to the sites (E and $A$ ) and depth of stimulation, cutaneous or muscular and gender. The Wilcoxon signed-rank tests for nonparametric values were used for analysis of these comparisons. The Spearman rank correlation coefficient tests were used for correlation between length of EMLA application times and VAS scores.

\section{Results}

Effects of EMLA and placebo on the skin of $E$ and $A$ sites (Table I)

When compared with placebo on site $E$, the difference was obvious: the VAS score with EMLA was lower than with placebo $(P=0.0001)$. Seventy-one percent of patients did 
TABLE I Effects of EMLA and placebo on skin. Visual analogue scale (Mean $\pm \mathrm{SD})$

\begin{tabular}{llll}
\hline Site & EMLA & Placebo & $P$ \\
\hline E & $0.75 \pm 1.36$ & $3.10 \pm 1.75$ & $*$ \\
A & $5.79 \pm 2.26 \dagger$ & $6.09 \pm 1.96 \ddagger$ & NS \\
\hline
\end{tabular}

Wilcoxon signed-rank test.

$* P=0.0001$ between EMLA and Placebo on E Cut

$\dagger P=0.0001$ between $\mathrm{E}$ and $\mathrm{A}$ with EMLA.

$\ddagger P=0.0001$ between $\mathrm{E}$ and $\mathrm{A}$ with placebo.

TABLE II Effects of EMLA and placebo in muscle. Visual analogue scale (Mean \pm S.D).

\begin{tabular}{llll}
\hline Site & EMLA & Placebo & $P$ \\
\hline E Musc $\dagger$ & $2.83 \pm 2.45$ & $5.73 \pm 2.30$ & $*$ \\
A Musc $\ddagger$ & $6.71 \pm 2.26$ & $6.37 \pm 2.29$ & NS \\
\hline
\end{tabular}

Wilcoxon signed-rank test.

${ }^{*} P=0.0001$ between EMLA and placebo on E Musc.

† Muscle extensor digitorum.

$¥$ Muscle abductor pollicis brevis.

not feel pain during skin insertion on that site. However, the A site pains, evaluated as worse than the $E$ site pains, were not affected by the application of EMLA.

\section{Effects of EMLA and placebo at needle insertion} in m.extensor digitorum and abductor pollicis brevis (Table II)

Extensor digitorum muscular pains were attenuated by the application of EMLA $(P=0.0001)$, but abductor pollicis brevis muscular pains, evaluated as worse than extensor digitorum muscular pains, were not affected by the application of EMLA.

\section{Correlation between length of EMLA application and VAS score}

The mean duration of EMLA application and placebo before EMG was $72.3 \mathrm{~min} \pm 22.2$ with a range of $45-140$ min. The Spearman rank coefficient did not show significant correlation between time and VAS scores in the range of application times measured in the present study.

\section{Gender and pain perception}

The female patients reported more pain than the male patients in all instances: on both sites $A$ and $E$, right and left, with and without EMLA, but the difference was not significant.

\section{Discussion}

The skin of the sites chosen for this study covers two of the muscles commonly explored in the normal course of
EMG. The skin of the palmar aspect of the hand and the skin of the forearm are anatomically and histologically different in two ways: nature of innervation and tegumental characteristics.

Our VAS results for untreated skin show a marked difference in pain perception between untreated $E$ and $A$ sites. The surveyed literature gives little information with regards to differences in pain perception on $E$ and $A$ sites. ${ }^{4-6}$ These sites are anatomically different: one $(A)$ is glabrous while the other $(E)$ is hairy. There are different innervation modalities between hairy and glabrous skin. The latter is characterized by the presence of rapidly adapting (RA) mechanoreceptors (Meissner corpuscles), slowly adapting receptors (Merkel cells), and Pacinian (PC) corpuscules. ${ }^{9}$ They are connected to A- $\beta$ axons not believed to be involved in noxious transmission. Two different types of nociceptive units have been identified for both hairy and smooth skin. High treshold mechanoreceptors (HTM) with A- $\delta$ axons and polymodal receptor units (PMN) with $\mathrm{C}$ axons. ${ }^{6}$ Either they are more numerous on the palmar aspect of the hand or they react differently. The greater force exerted to insert the EMG needle into the stiffer skin may activate HTMs to a greater degree. It is also possible that tissue damage is more extensive in the thenar eminence because of the greater strain imposed to the non-compliant epidermis and underlying tissues. Thus, more PMNs would be activated. Although their role in primary hyperalgesia is controversial, ${ }^{4}$ they or some other nociceptors may account for the release of algogenic peptides causing hyperalgesia. It is possible that primary hyperalgesia alone can explain the difference in pain perception.

Our results also show clearly that the VAS of A site shows no difference between EMLA and placebo while there is a marked difference on $\mathrm{E}$ site. This dissimilarity may be caused by the absence of penetration of EMLA on the thenar eminence while there is effective penetration on $E$ site. Beside free nerve endings variations, there is also a wide difference in the skin histology of the two studied sites. The skin covering the thenar eminence (A) is commonly known as thick skin while the skin covering $E$ site is a thin skin. ${ }^{7}$ Thick skin covers the palms of the hands and the soles of the feet. The term thick skin does not refer to the skin as a whole but to the thickness of the epidermis. The epidermis of the palms and soles has five distinct layers, in constant evolution towards the formation of the outermost mature structure, the stratus corneum. The outcome is a tough, keratinous membrane prone to desquamation and thicker than the skin covering other parts of the body. 'It covers the inner aspect of the hands and renders it more resistant to trauma and penetration of all kinds especially in manual workers' hands. In the present study, if we refer to the VAS scores, our results suggest that 
EMLA did not penetrate the thick thenar skin in most of our patients.

Thin skin covers the rest of the body. There, all layers are thinner, less distinct, and evolve to a lesser degree of keratinization and relatively less impermeability. The difference in thickness of thin skin between different parts of the body surface results from the thickness of the dermis. Measurements made in the middle of the forearm with a caliper by Bjeeriing and Arendt-Nielsen ${ }^{8}$ have shown that on a site close to the $E$ site, the skin has a mean thickness of $3.35 \mathrm{~mm}(\mathrm{SD} \pm 0.70)$. In their study sensory and pain threshold measurements showed that EMLA had penetrated the skin of the forearm after $\mathbf{4 5}$ minutes. The pain threshold exceeded thin skin depth after $90 \mathrm{~min}$ to $120 \mathrm{~min}^{8}{ }^{8}$ This depth of penetration may explain the superiority of EMLA found over lidocaine infiltration for arterial cannulation ${ }^{3}$ and the lower level of pain felt during intravascular placement of $i v$ needle once the skin has been penetrated.' It may also explain why the muscle insertion pain VAS scores were less on the treated $E$ site in our study.

We could not correlate our findings with the duration of application of EMLA, as did others, ${ }^{2.8}$ but the efficacy of EMLA is noticeable well before the 45 min delay. ${ }^{9}$ The results on A site may have been different if we had waited for longer, but as our aim was to ease the discomfort of a painful procedure during a regular EMG clinic, our investigation was kept within acceptable time limits.

Another factor to explain the variability of results is the wide range of responses in a normal population and this variability could have been greater in our population. As there was an indication for EMG, the patients were already suspected of some neuromuscular disorders which could have changed the results.

In summary, in a clinical practice, we found EMLA to be efficacious in easing the painful prickling of the skin and the muscle underneath, but only on the more proximal site. The pain of the needle insertion was not affected by EMLA application on the thenar area. This may have resulted from histological differences between the thenar and the proximal area. We think that EMLA may still be beneficial during EMG, as most of the explored muscles are outside the thick skin areas, especially in patients apprehensive of needling.

\section{Acknowledgements}

We wish to acknowledge the help of Dr. Jean-Pierre Tétrault for his useful advice on statistics and Astra Pharma Inc. whose help was essential in the completion of this study.

\section{References}

1 Evers $H$, Von Darnel O, Juhlin L, Ohlsén L, Vinnars E. Dermal effects of compositions based on the eutectic mixture of lignocaine and prilocaine (EMLA). Br J of Anaesth 1985; 57: 997-1005.

2 Ehrenström-Reiz S, Reiz S, Stockman O. Topical anaesthesia with EMLA, a new lidocaine-prilocaine cream and the cusum technique for detection of minimal application time. Acta Anaesthesiol Scand 1983; 27: 510-2.

3 Smith $M$, Gray BM, Ingram S, Jewkes DA. Double-blind comparison of topical lignocaine-prilocaine cream (EMLA) and lignocaine infiltration for arterial cannulation in aduits. Br J Anaesth 65: 240-3.

4 Raja NR, Meyer AM, Campbell JN. Peripheral mechanisms of somatic pain. Anesthesiology 1988; 68: 571-90.

5 Winlelmann RK. Cutaneous Sensory Nerves. In: Seminars in Dermatology. 1988; 7: 236-68. Philadelphia: W.B. Saunders Company.

6 Lynn B. Cutaneous Sensation. In: Lowell A Goldsmith (Ed.). Physiology, Chemistry and Molecular Biochemistry of the Skin. 2nd ed., London: Oxford University Press, 1991; 779-815.

7 The Skin and its Appendages (The Integument). In: Textbook of Histology. Leeson CR, Leeson TS, Paparo AA 5th Ed., Philadelphia: WB Saunders Company, 1985; 291-309.

8 Bjerring, Arendt-Nielsen L. Depth and duration of skin analgesia to needle insertion after topical application of EMLA cream. Br J of Anaesth 1990; 64: 173-7.

9 Nott MR. Relief of injection pain in adults EMLA cream for 5 minutes before venepuncture. Anaesthesia 1990; 45: $772-4$. 